\title{
On the structure and development of the lemon.
}

\author{
L. S. ROSS.
}

\section{(WITH PLATE XVI.)}

The mature lemon has its own characteristic lemon color; it is oval in outline and varies in size. The rind is rough, thick and leathery, and affords much protection to the seeds and pulp within. By looking closely at the rind, small dark specks may be seen which indicate the position of oil glands. If a piece of the peel be bent or crushed together suddenly near a flame, the oil will be forced out in minute quantities and will burn with a beautiful flame. If a cross section of the lemon be made, it will at once be seen that narrow white bands pass from the rind to a central spongy mass forming from seven or eight to eleven or twelve isosceles triangles whose apices are toward the center of the fruit. The white bands are the cut edges of walls extending through the entire length of the fruit dividing it into chambers or loculi which contain the seeds and pulp. Near the bases of the triangles their common walls divide, one division going to form the base of one triangle, while the other division passes in an opposite direction to form the base of the adjoining triangle. When a lemon or an orange is "quartered" the line of division begins at the angle where the wall between the loculi divides and passes along the center of the wall showing that it is double. The loculi are seen to be filled with the pulp mass which can be separated into many "clubs," some space is generally occupied by the seeds, but by far the greater part by the pulp. The pulp clubs have a very delicate straw color and are semi-transparent; their shape and size varies according to their position in the loculus. They are all attached to the back of the loculus, that is to the side of the loculus next the rind, hence those lying toward the center of the fruit are longer than those lying nearer the rind. The long clubs are usually summetrical and consist of a tapering body with a long attenuated stalk for attachment. Those nearer the rind have shorter stalks. The clubs that come in contact with the seeds ac-

1 The following notes give the results of studies on the lemon, Citrus limonum $L_{\text {n }}$ carried on during the spring of 1890 in Presults of studies on the lemon, Citrus limomiversity of Illinois. The illustrations of 1890 in Professor Burrill's laboraiory at the Univeres my thanks to Mr. C. W. Butler, of St. Petersburg, Fla., for his kindness in supplying me with
specimens of young fruit. 
quire any shape necessary to conform to the outline of the seed; also those near the extremities of the loculi are irregular in shape. On crushing the pulp the acid juice is forced out ; and it will be noticed that the clubs near either extremity are sometimes harder than those nearer the center and do not contain as much juice. The cross section may lay bare the seeds growing from the inner angles of the loculi and imbedded among the pulp. Sometimes only abortive seeds are found, or sometimes abortive and developed. In the center of the section will be seen a white, spongy circular mass whose perimeter is formed by the lines of the inner rounded angles of the loculi. These lines are curved in such a way that their convexities are turned toward the center of the circle. Here the same division of the walls of the loculi will be noticed as at the back. By looking closely several spots may be discovered in the spongy center near the perimeter, one occuring at each angle formed by the curved lines of the perimeter.

The rind is of the lemon color about one-third of its thickness, the other two-thirds being white. The large, dark oil glands are quite conspicuous, extending even inside the yellow part into the white part of the rind. By looking carefully, many small, dark specks may be distinguished distributed through the white rind. One speck may be found at the center of the back of each loculus and also one in the angle at the juncture of any two loculi.

The cross section of the mature lemon presents a radial arrangement like the wheel of a wagon; the center spongy mass being the hub, the white part of the rind representing the felloes, the yellow part the tire, and the walls of the loculi the spokes, while the wheel is made solid by the filling of pulp clubs. For the illustration of the cross section of the mature lemon, see fig. I.

In the very young lemon the style is the most prominent part; it is not much less in diameter than the ovary and is two or three times as long, with the upper end slightly enlarged. After the fruit has become about 4 or $5 \mathrm{~mm}$. in diameter the style drops off and the fruit assumes the shape it retains through growth to maturity. The color is yet dark green, the lemon color not being attained until maturity. A cross section of a fruit $2 \mathrm{~mm}$. in diameter shows the loculi already present, but without the pulp clubs. The rind and the walls of the loculi are relatively very much thicker and the solid center column much larger than in the mature fruit. At a 
later stage the ovules are present in the loculi as club-shaped protuberances arising from their inner angles as represented in fig. 2. The loculi are relatively larger than in the younger stage.

If a microscopical examination of the cross section of the mature lemon be now made, the rind is seen to be made up of cells of various shapes and sizes. The epidermis is a thin layer in which the cells are thin-walled, empty and colorless; these cells are small in size and rectangular in shape. Next to the epidermis appears a layer of thin-walled palisade cells, thenfollow cells containing chromatophores, some partially filled, others full. The oil glands are located in the yellow part of the rind, some times extending into the white. They are large structures visible to the naked eye; their walls are composed of thin-walled rectangular cells so arranged as to give the glands a circular or oval shape when seen in outline. Inside the colored is the white portion of the rind, which is made up of loose spongy parenchyma with elongated cells. The small specks mentioned as being visible without the microscope will be seen to be fibro-vascular bundles, some of which are found to extend through the length of the lemon, while others form a net-work with the principal bundles and one another. A large bundle is seen at the center of the back of each loculus, and one also at the angle between any two loculi. The other smaller bundles are found sometimes with a rather regular arrangement, at others, apparently scattered promiscuously throughout the rind (see fig. I). Some sections lay bare bundles lying at right angles with the long axis of the lemon. The specks noticed in the center column are seen to be fibro-vascular bundles also. The center column is composed of large-celled, spong! parenchyma. The dissepiments between the loculi are composed of spongy tissue with tougher thicker-walled tissue on either side. The pulp clubs are of a very delicate structure the wall is composed of elongated narrow cells parallel with the long axis of the club (fig. 3). The inner part of the club is divided into large very thin-walled cells, which contain the juice (fig. 4). The tissue forming the wall of the club is an outgrowth from the thickened cells of the dissepiment walls, while the inner juice cells are a continuation from the spongy parenchyma at the back of the loculi.

Let us now turn to the development and inquire what are 
all these structures and what is their derivation. It has long been known that flowers and fruits are produced from whorls of especially developed leaves. Let us compare a mature leaf with one of the loculi, and note the similarities (figs. 5 and 6 ). In the leaf a large midvein extends through the whole length, gradually tapering from the base toward the tip. A very small irregular marginal vein is seen, and a short space inward from the marginal vein and connected with it at various places. is a submarginal vein. A hand magnifier is needed to make out the marginal vein in the leaf. From the midvein other veins pass obliquely toward the margin; from these again minute branches pass off, forming a close network of veins. Now let us examine a loculus. Along the center of the back is a large fibro-vascular bundle slowly tapering toward the tips. With this bundle many others are connected, which form a network over the back of the loculus, similar to the network of veins on the back of the leaf. The meshes formed by the bundles are larger toward the base of the loculus than at and beyond the center. It will be seen in a side view of a loculus (fig. 7 ) that a large bundle passing along its inner angle through the center column curves about the end of the loculus and passes back along the upper lateral angle to the end from which it started. This is the bundle previously mentioned in the description of the cross section as being seen at the angle between any two loculi. The only way in which I can account for this fibro-vascular bundle and its peculiar shape, is that it is formed by the marginal and submarginal veins of the leaf. As has already been noticed, there are several points of connection between these veins so that by the development of the vein connecting them, at or below the place where the style drops off, the required curve is made and the bundle receives its shape. One fact favoring this supposition is that the pulp clubs are not attached to the side walls but to the back of the loculus. The great development of the space between the marginal and submarginal veins of the leaf necessary to form the side of the loculus would not be favorable to the development of the leaf hairs of that region. Another favorable $f_{a c t}$ is that a longitudinal section of a fruit before the pistil has fallen, if made at the right place, shows the bundle already curved about the loculus at a very short distance from the pistil. The fibro-vascular bundles in the rind at right angles with the large mid bundles probably represent small veins passing from the larger veins to the surface of the leaf. 
The bundles appear when the fruit is first formed, and change their relative position somewhat as development progresses. The loculi vary in number in different lemons; some specimens having seven or eight and others as many as eleven or twelve. Each loculus represents a carpellary leaf. The leaf is folded with the upper surface inward toward the axis. The margins are again folded where they meet and project a short distance away from the axis about which the carpellary leaves are gathered. These infolded margins form the placentæ upon which the ovules are borne. The ovules appear at a very early stage of development. The nucleus is first seen toward the top, but it afterwards grows towards the base. Two rows are in each loculus, one upon either margin of the carpellary leaf. Often only one ovule develops, sometimes neither; for this cause the number of seeds in different specimens varies much. In a young fruit, $4 \mathrm{~mm}$. in diameter, the ovules are quite large, having two walls enclosing a nucleus. Fig. 8 shows a cross section of a loculus with both ovules developing; the section is such that the ovules are cut near the upper part, exposing the nuclei of the young seeds. The spongy center column forming the axis of the lemon is a development from the infolded margins of the leaf. The pulp clubs are derived from the leaf hairs, and first appear as blunt protuberances from the back wall of the loculus. They gradually enlarge and elongate until they fill up the space of the loculus crowding about the seeds and lying close upon one another, but not structurely united.

From all this we see that every part of the fruit has its origin from some part of the leaf.

A cross section through a pistil shows a set of fibro-vascular bundles in a circle about half way between the center and the perimeter. The bundles are of a complicated structure, being divided by rows of small empty cells. Toward the upper end of the pistil only one circle of bundles appears; farther down another circle makes its appearance nearer the perimeter of the section. The inner circle seems to continue through the length of the pistil into the fruit. Another section through a pistil shows very broad narrow bundles, the breadth of a bundle being about one-half the
radius of the pistil.

in diametion through the upper end of a lemon one-half inch surrounded by the fibro-vascular bundles as narrow bands unded by regular rows of cells, the row next the dense 
center being filled with a granular substance (fig. 9). Around this row are one or two regular rows of thick-walled cells and others irregularly arranged. Near the perimeter of the section are the oil glands formed by regular rows of rather narrow, elongated, rectangular cells ; and about these are irregularly arranged cells. Next the perimeter the cells are small, but the size increases further inward to the fibrovascular bundles, between which, and in the center column, the cells are smaller.

A section through the same specimen at the beginning of the loculi shows some small fibro-vascular bundles surrounded by very small, empty, thin-walled cells. The bundles in the center column are broad and narrow, but further into the interior of the fruit they become rounded and smaller. The oil glands are well developed.

Explanation of Plate XVI.-Fig.1. Cross section of mature lemon, showing half the section; $a$, yellow part of rind; $b$, white part of rind; $c$. loculus filled with pulp; $d$, spongy center colnmn; $e$, double wall of the loculi; $f$ and $g$, fibro-vascular bundles. Fig 2. Cross section of young fruit $3.5 \mathrm{~mm}$. in diam.; $a$, loculus; $b$, ovule; $c$, center column; $d$, fibrovascular bundle; $e$, oil gland; $d^{\prime}$, fibro vascular bundles of rind; $f$, rind, Fig. 3. Cells of wall of pulp club. Fig. 4. Cells containing juice in the pulp clubs. Fig. 5 . Leaf; $a$, midvein; $b$, smaller veins; $c$, marginal vein; $c^{\prime}$, submarginal vein. Fig. 6 . Back of loculus; $a$, large fibro vascular bundle; $b$, smaller bundles forming a network. Fig. 7 . Side view of loculus; $a, a$, curved fibro-vascular bundle; $b$, back of loculus; $c$, minute bundles seen in side wall of loculus. Fig. 8. Loculus showing both ovules developing, the section being such that the nuclei are exposed; $a$, loculus; $b$, nucleus of seed; $c$, inner wall about nucleus; $c^{\prime}$, outer wall of ovule; $a^{\prime}$, ovule. Fig 9 . Section through upper end of lemon $\frac{1}{2}$ in. in diam.; $a$, epidermis; $b$, cells about oil gland $c ; d$, cells of rind; $e$, dense center of fibro-vascular bundle; $f$, cells about center.

Champaign, Ill.

\section{EDITORIAL.}

THE APPEARANCE of Dr. Merriam's report of a biological survey of the San Francisco mountain region of Arizona (noticed elsewhere in this number) suggests a timely topic for botanists to consider. This same subject was prominently before the botanists of the American Association at their Indianapolis meeting, in considering the geographical distribution of North American plants. The notion that a plant is only valuable because it is a new or rare species, and that it makes no special difference as to its exact locality, its soil conditions, or its altitude, is one that should 


\section{$2 \mathrm{BHL}$ Biodiversity Heritage Library}

Ross, L S . 1890. "On the Structure and Development of the Lemon." Botanical gazette 15(10), 262-267. https://doi.org/10.1086/326576.

View This Item Online: $\underline{\text { https://www.biodiversitylibrary.org/item/90530 }}$

DOI: https://doi.org/10.1086/326576

Permalink: https://www.biodiversitylibrary.org/partpdf/221930

\section{Holding Institution}

Missouri Botanical Garden, Peter H. Raven Library

\section{Sponsored by}

Missouri Botanical Garden

\section{Copyright \& Reuse}

Copyright Status: Public domain. The BHL considers that this work is no longer under copyright protection.

This document was created from content at the Biodiversity Heritage Library, the world's largest open access digital library for biodiversity literature and archives. Visit BHL at https://www.biodiversitylibrary.org. 